\title{
УДК 122/129
}

\section{NONLINEARITY OF THE EDUCATIONAL PROCESS: SYNERGETIC APPROACH}

\section{НЕЛІНІЙНІСТЬ ОСВІТНЬОГО ПРОЦЕСУ: СИНЕРГЕТИЧНИЙ ПІДХІД}

Koperlos R.Yu. / Коперльос Р.Ю.

PhD in philosophy, Assistant Professor of Philosophy and Methodology of Science / к.фiлос.н., асистент кафедри філософії та методології науки ORCID: 0000-0002-4896-2407

Taras Shevchenko National University of Kyiv, Kyiv, Vladimirskaya, 64/13, 01033 Київський національний університет імені Тараса Шевченка,

Київ, Володимирська 64/13, 01033

\begin{abstract}
The idea of considering the nonlinearity of the educational process is due to the transition of science from classical to non-classical and post-classical stages of its development. Paradigmatic shifts that require semantic explication of understanding the educational process in a particular discourse are associated with a synergetic research program and the formation of complex and nonlinear styles of scientific thinking. The methodological perspective through which the study took place gave a holistic view of the understanding of the nonlinearity of the educational process and all its components and components. Based on the synergetic approach, the understanding of nonlinearity of educational process and nonlinearity of personalities of educational process as active subjects of «teacher-student» relationship, which are capable of selforganization, self-development, self-regulation, self-analysis and self-realization, and are carriers of nonlinear thinking. The importance of understanding the nonlinearity of the educational process in modern post-classical discourse is clarified and the methodological potential of the nonlinear approach is investigated.
\end{abstract}

Key words: personality, nonlinearity, teacher, student, synergetic approach.

\section{Introduction.}

The emergence of the concept of «nonlinearity» in modern scientific discourse is associated primarily with the formation of post-classical scientific rationality. The term «post-classical rationality» was proposed by V. Stepin, who distinguished between classical, non-classical and post-classical types of rationality [3]. In modern post-classical discourse, a significant number of works are devoted to the problems of implementation principles of nonlinear approach in education. In particular, nonlinearity is one of the methodological foundations on which based on the modern educational paradigm, and is also fundamental the principle of organization of the educational process. Considering the educational process as one that is nonlinear, we can see that not only is it nonlinear, but its components are also nonlinear. That is, we can talk about the nonlinearity of individuals who are involved in the educational process.

\section{Main part.}

1. Synergetics in the educational space.

Post-non-classical science is human-dimensional, that is, in any study it is impossible to avoid or abstract from human participation, because human activity is closely linked to complex human-dimensional systems: social, political, economic, environmental, educational, etc. In addition, in post-non-classical science, the role of synergetics as a scientific picture of the world and research methodology is growing. 
And at the same time are beginning to analyze the innovation processes of education systems through a synergistic approach. But it is worth noting that synergistic methodology can be applied in the educational field only when the philosophy of education regards educational processes as self-organizing. It should be borne in mind that synergetics can most meaningfully describe complex nonlinear processes in education, investigate its disordered nature, and, as a consequence, solve many problems in the field of education.

The concept of synergism in education is gaining momentum recently. This concept states that education representatives now need to learn how to introduce selforganizing and creative character into the learning process rather than trying to overcome the chaos of the learning process and personality. It is necessary to take into account not only that the educational process is nonlinear in nature, but also that the education system is formed into four main components:

1) the object of education - student;

2) the purpose of education;

3) training (education, development);

4) educational tools - material base, teachers and others.

When we consider these components together with key synergetics provisions and concepts (integrity, openness, nonlinearity, chaos, complexity, etc.), we will get new provisions (solutions, approaches). Here are some of them:

- holistic nature of training and development;

- behavioral, thinking, spiritual, outlook and personal openness of the object of education to the environment;

- the complex nature of the personality of each individual objects and means of education;

- probable result of training, upbringing and development.

Thus, synergetics has recently started to be actively introduced into the field of education, which has affected the application of a synergistic approach to the analysis of the educational space and the formation of a new direction in pedagogy, namely synergetic pedagogy.

\section{Understanding the nonlinearity of personality in the educational process.}

The idea of considering the nonlinearity of individuals in relation to the "teacher-student" is due to the transition of science from classical to post-classical stages of its development. Paradigmatic shifts that require semantic explication of the "teacher-student" relationship in a certain discourse are associated with a synergetic research program and the formation of complex and nonlinear styles of scientific thinking.

An important problem is the rethinking of the term «personality» of the components of the relationship «teacher-student» as those that are nonlinear in themselves and interact in a nonlinear way. In this case, we can talk about the teacher and the student as active subjects of the educational process, which are capable of self-organization, self-development, self-regulation, self-analysis and self-realization, both in relation to «teacher-student» and separately from each other in terms of distance learning. Interestingly, the active subject is able to regulate, organize the life manifestations of other individuals, to influence their self-organization and self- 
development, but here we mean the influence of the active subject on the passive.

The individual is obliged to stop being a passive observer and to show himself as an active subject, aware of the instability, according to which even small fluctuations make open and unpredictable scenarios / situations / events. In this case, we understand that the subject can only choose from a set of possibilities and / or possible scenarios for the development of a phenomenon, event, etc., the most desirable or priority scenario, which, in turn, will open the next new set of unforeseen events and scenarios. That is, in the period of instability, it is chance to choose the further development of events and it is the individual who is capable of such a choice. Therefore, it can be said that a person who is capable of self-development and is in a state of «necessity» and «chance», with the help of nonlinear thinking inherent in it, is able to distinguish these dialectical opposite categories and distinguish nonlinear relationship of instability and balance.

The use of a synergetic approach to the interpretation of the nonlinearity of personalities of each of the components of the «teacher-student» relationship involves identifying their activity, dialogue, independence, creativity, initiative and identifying their will to choose a strategy for the educational process. In addition, we can talk about the style of teaching and communication that the teacher chooses, based on their personal orientations, and which will affect the atmosphere of the "teacherstudent» relationship. Conversely, the style of communication that the student chooses in relation to the teacher is an independent choice based on their own experiences and considerations.

Thus, it can be argued that the teacher and student are nonlinear individuals with a complex nonlinear thinking style of the teacher-student relationship, ie, are active actors capable of self-organization, self-development, self-regulation, self-analysis, self-realization, creativity, activity, choice of behavior and communication with each other, etc.

\section{Nonlinear of education.}

The concept of nonlinearity is considered discursive in modern philosophy of education. Its introduction to the explanation of the educational space allows the use of a synergistic approach to different educational processes and educational elements / components. Modern post-classical discourse should include in the problem circle of the educational process the concept of nonlinearity as a certain foundation on the basis of which educational problems are seen in different dimensions and perspectives. For example, M. Ozhevan develops models of education where he offers an understanding that education loses its inherent tradition: linearity and certainty, and acquires the features of nonlinearity and uncertainty [2].

The nonlinear approach in education is implemented in the following areas:

1) there are ideological changes in the education system. The basic approach to learning in the context of nonlinearity is the formation of a holistic vision of the world, which in turn should be realized through a sense of personal interaction, responsibility, probabilistic perception and unpredictability of results.

2) changes in the understanding of the essence of man as a nonlinear personality. This implies the nonlinearity of all individuals involved in the educational process. However, it should be noted that such individuals will be nonlinear only in the social 
world, in interactions, activities, work, etc., because the person himself is not a nonlinear person.

V.G. Kremen writes «the society of the XXI century as a whole rightly called the «knowledge society», because it is knowledge that defines and material and spiritual life. Naturally, people spend more and more time to obtain them. This is due to the fact that the information potential of society, like a chain reaction, is constantly increasing both in space and time, penetrating deeply into the essence of natural and social phenomena» [1, p. 33].

\section{Conclusion.}

Each of the components of the educational process is capable of selforganization, self-development, self-regulation and self-realization, and hence the interaction with unstable and unpredictable consequences of this influence. Thus, thanks to the synergetic approach, it turns out that not only the educational process is nonlinear, but each of its components, ie, are active actors capable of selforganization, self-development, self-regulation, self-analysis, self-realization, creativity, activity, style choice behavior and communication with each other, etc.

The nonlinearity of the educational process manifests itself in the nonlinearity of education as a system and as a process, the subjects of cognitive and educational communications, the constant nonlinearity of educational material, as well as methodical, professional, systematic, meaningful work of all involved in the educational process.

\section{References:}

1. Kremen V.G. Education and science in Ukraine - innovative aspects. Strategy. Realization. Results / VG Flint. - K.: Грамота, 2005. - 448 c.

2. Ozhevan M. Communicative model of education in the era of nonlinear thinking / M. Ozhevan // Higher education of Ukraine. - 2003. - № 3. - P. 29-35.

3. Stepin B.C. Scientific knowledge and values of technogenic civilization / V.S. Stepin // Questions of Philosophy. - 1989. - No. 10. - P. 3-18.

Анотація. Ідея розгляду нелінійності освітнього процесу зумовлена переходом науки від класичного до некласичного $i$ постнекласичного етапів ї̈ розвитку. Парадигмальні зрушення, щзо вимагають змістовно-смислової експлікації розуміння освітнього прочесу в певному дискурсі пов'язані із синергетичною дослідницькою програмою $i$ формуванням складного та нелінійного стилів наукового мислення. Методологічний ракурс, через який відбувалося дослідження, дав иілісне уявлення про розуміння нелінійності освітнього процесу та всіх його компонентів та складових. На основі синергетичного підходу виведено розуміння нелінійності освітнього процесу та нелінійності особистостей освітнього прочесу як активних суб'єктів відношення «викладач-студент», які здатні до самоорганізації, саморозвитку, саморегуляції, самоаналізу та самореалізації, $i$ є носіями нелінійного стилю мислення. 3'ясовується значення розуміння нелінійності освітнього процесу в сучасному постнекласичному дискурсі та досліджується методологічний потенціал нелінійного підходу.

Ключові слова: особистість, нелінійність, викладач, студент, синергетичний підхід.

Стаття відправлена: 08.11.2021 г. (C) Коперльос Р.Ю. 